\title{
Pengaruh Ekstrak Etanol Kulit Apel Manalagi (Malus Sylvetris Mill) Berbagai Dosis Dalam Mencegah Penurunan Berat Badan Bayi Tikus Baru Lahir Pada Tikus (Rattus Norvegicus) Bunting Yang Dipapar Asap Rokok
}

\author{
Retno Rahma Dila ${ }^{1}$, Setyawati Soeharto ${ }^{2}$, Mustika Dewi ${ }^{3}$ \\ 1) Program Studi S1 Kebidanan, Fakultas Kedokteran, Universitas Brawijaya, Email: \\ dretnorahma@yahoo.com, Telp: 085295431314 \\ ${ }^{2}$ Laboratorium Farmakologi, Fakultas Kedokteran, Universitas Brawijaya, Email: \\ ${ }^{3}$ Program Studi S1 Kebidanan, Fakultas Kedokteran, Universitas Brawijaya, Email: \\ mustikadewi@ub.ac.id
}

\begin{abstract}
Backgorund: Infant mortality rate is an indicator of health development written in the Social Medium-Term Development Plan of 2015-2019. One of the reasons behind the high infant mortality rate is low birth weight. Smoke exposure on the pregnant mother might be the trigger. Smokes from cigarettes contain free radicals that may cause disorders to the fetus growth. Purpose: To prove the effect of the ethanol extract of Manalagi Apple peel in various dosages to prevent weight loss on baby rat born from pregnant rat that is exposed to smoke. Method: This research used Randomized Post Test Only Control Group Design by comparing the weight of newborn baby rats from 5 groups. There were 5 pregnant rats in each group. $K$ - was a group with no administration of apple peel's ethanol extract and no exposure to smoke, while $K+$ was a group that was exposed to smoke and not administered with ethanol extract of apple peel. Group P1 (7 $\mathrm{mg} / \mathrm{Kg} \mathrm{BB})$, P2 (14 mg/Kg BB), P3 (28 $\mathrm{mg} / \mathrm{Kg} \mathrm{BB}$ ) were groups that were administered with ethanol extract of apple peel in 3 different dosages and exposed to smoke. The administration of apple peel ethanol extract and the smoke exposure were conducted in day 6 until day 19 of pregnancy. The research result data was analyzed using One Way Anova, Post Hoc Test and Pearson Correlation Test. Result: The weights of newborn rats on $K+$ group were smaller than $K$ - and the difference was significant $(p=0,004)$. Group P1, $P 2$, and $P 3$, had significant difference with $K+$, but not with $K-$. Conclusion: Apple peel's ethanol extract can prevent weight loss on newborn rat and the effective dose is $7 \mathrm{mg} / \mathrm{Kg}$ $B B$.
\end{abstract}

Keywords: Low Birth Weight, Cigarette Smoke, Manalagi Apple's Peel, Pregnant Rat

\section{ABSTRAK}

Latar belakang: Angka Kematian Bayi (AKB) merupakan salah satu acuan pembangunan kesehatan yang tertuang dalam Rencana Pembangunan Jangka 
Menengah Sosial (RPJMN) 2015-2019, salah satu penyebab tingginya AKB adalah bayi lahir dengan berat badan rendah. Faktor lingkungan paparan asap rokok pada ibu hamil dapat menjadi pemicunya. Asap rokok mengandung radikal bebas yang dapat menyebabkan gangguan pertumbuhan janin. Tujuan: Membuktikan pengaruh ekstrak etanol kulit apel manalagi dalam mencegah penurunan berat badan bayi tikus baru lahir pada tikus bunting yang dipapar asap rokok. Metode: Penelitian ini menggunakan rancangan Randomized Post Test Only Control Grup design, dengan membandingkan berat badan bayi tikus baru lahir dari 5 kelompok. Terdapat 5 tikus bunting dalam setiap kelompok. K- adalah kelompok tanpa pemberian ekstrak etanol kulit apel dan tanpa di papar asap dari rokok, $\mathrm{K}+$ yaitu yang di papar asap dari rokok tanpa ekstrak etanol kulit apel. Kelompok P-1 (7 mg/ KgBB), P-2 (14 mg/KgBB), P-3 (28 mg/KgBB) merupakan kelompok yang diberikan ekstrak etanol kulit apel dengan 3 dosis yang berbeda dan dipapar asap rokok. Pemberian ekstrak etanol kulit apel manalagi dan paparan asap rokok dilakukan pada hari ke-6 hingga hari ke-19 kebuntingan. Data hasil penelitian dianalisis menggunakan One Way Anova, Post Hoc Test dan Uji Korelasi Pearson. Hasil: Berat badan bayi tikus baru lahir pada tikus $\mathrm{K}+$ lebih kecil dibandingkan $\mathrm{K}$ - dan berbeda signifikan $(p=0,004)$. Kelompok $\mathrm{P} 1, \mathrm{P} 2$, dan P3 dibandingkan dengan $\mathrm{K}+$ memiliki perbedaan yang signifikan, namun apabila dibandingkan dengan $\mathrm{K}$ - tidak berbeda signifikan. Kesimpulan: Ekstrak etanol kulit apel dapat mecegah penurunan berat badan bayi tikus baru lahir dan dosis efektif penggunaannya yaitu $7 \mathrm{mg} / \mathrm{Kg} B B$.

Kata Kunci: Asap Rokok, BBLR, Ekstrak Etanol Kulit Apel Manalagi, Tikus Bunting

`Korespondensi: Retno Rahma Dila. Surel: dretnorahma@yahoo.com

\section{PENDAHULUAN}

Menurut Survey Demografi Kesehatan Indonesia, menunjuk kan tahun 2002 Angka Kematian Bayi (AKB) mencapai 35 per 1000 kelahiran hidup dan tahun 2015 menjadi 22,23 per 1000 kelahiran hidup ${ }^{1}$. Salah satu penyebab tingginya $A K B$ yang biasa terjadi yaitu Bayi Berat Badan Lahir Rendah (BBLR). Angka kejadian BBLR secara nasional pada tahun 2013 mencapai 10,2\% dan dari total jumlah bayi BBLR nasional 11,2\% nya berasal dari Jawa Timur ${ }^{2}$, pada Kota Malang yaitu mencapai 428 kasus BBLR pada tahun $2014^{3}$. Sebuah penelitian Rasyid, dkk pada tahun 2012 menyatakan bahwa salah satu faktor resiko terbesar penyebab BBLR adalah paparan asap rokok ${ }^{4}$.

Perilaku merokok saat ini telah menjadi kebiasaan umum di imasyarakat yang jumlahnya tidak sedikit. Pada jumlah perokok harian, Indonesia menempati posisi ketiga $^{5}$. Peningkatan jumlah perokok setiap tahunnya, akan mempengaruhi jumlah perokok pasif yang menerima paparan asap rokok. Saat ini Jumlah rumah tangga yang menjadi perokok pasif sebesar $85 \% 6$.

Ibu hamil yang terpapar asap rokok sejak awal kehamilannya akan dapat menurunkan berat plasenta sehingga menyebabkan menurunya fungsi plasenta yang hasil akhirnya akan terjadi $\mathrm{BBLR}^{7}$. Dalam asap rokok mengandung molekul radikal bebas. Radikal bebas yaitu senyawa oksigen reaktif yang merupakan senyawa dengan elektron yang tidak berpasangan ${ }^{8}$. Radikal bebas akan menjadi berbahaya apabila jumlah nya berlebiihan dan lebih banyak dari jumlah antioksidan yang berada 
dalam tubuh. Apabila terjadi ketidak seimbangan antara jumlah radikal bebas dan antioksidan dalam tubuh maka akan dapat menyebabkan terjadinya stres oksidatif ${ }^{8}$. Stress oksidatif dapat menyebabkan disfungsi endotel vaskuler yang menyebabkan vasokontriksi pada arteriola spiralis. Dampak akibat terjadinya vasokontriksi yaitu hipoperfusi sirkulasi uteroplasental sehingga suplai oksigen dan nutrisi ke janin akan menurun, hal ini dapat menyebabkan bayi lahir dengan berat rendah ${ }^{9}$.

Pencegahan yang dapat
dilakukan untuk mengurangi
terjadinya BBLR yaitu dengan
menjaga keseimbangan antioksidan
dan radikal bebas dalam tubuh,
sehingga tidak timbul stress
oksidatif dalam plasenta.
Pemenuhan kebutuhan antioksidan dapat diperoleh dari buah, sayur, dan biji-bijian. Salah satu buah yang memiliki kandungan antioksidan yaitu apel manalagi (Malus sylvetris Mill) ${ }^{10}$ Produksi apel manalagi di Malang pada tahun 2012 sebanyak 328,86 kwintal per tahun ${ }^{11}$ dan untuk limbah kulit apel manalagi yang berasal dari hasil pengolahan keripik apel mencapai 42,308 \% dari total produksi apel pada tahun 201012. Jumlah dari limbah kulit apel yang tidak sedikit, dapat dimanfaat kan menjadi salah satu alternatif pemenuhan kebutuhan antioksidan.

Pemilihan kulit apel didasarkan pada kandungan kulit apel jenis manalagi yang terdapat fitokimia turunan polifenol yaitu, quersetin, phloridzin, dan clorogenic acid. Senyawa polifenol terdapat pada kulit apel manalagi tersebut lebih banyak dari pada buahnya ${ }^{10}$.
Kandungan kuersetin pada kulit apel yaitu $4,4 \mathrm{mg} / 100$ gram dan secara in vitro, kuersetin memiliki aktivitas antioksidan yang lebih besar dari vitamin $A$ dan $E^{13}$. Sejauh ini belum ada penelitian terhadap manfaat kulit apel sebagai salah satu pilihan untuk pencegahan BBLR pada ibu hamil yang terpapar asap rokok. Berdasarkan alasan tersebut, akan diteliti mengenai manfaat kulit apel sebagai salah satu alternatif pilihan nutrisi pada ibu hamil yang terpapar asap rokok sebagai antioksidan.

\section{METODE PENELITIAN Desain Penelitian}

Pada penelitian mengguna kan desain true experimental dan rancangan Randomized Postest Only Control Group Design. Sampel terbagi dua kelompok yaitu, kelompok kontrol dan kelompok perlakuan. Kelompok kontrol terbagi menjadi dua yaitu kontrol positif $\left(\mathrm{K}_{+}\right)$ adalah tikus bunting yang dipapar asap rokok tanpa diberikan ekstrak etanol kulit apel manalagi dan kelompok kontrol negatif (K-), tikus bunting tanpa dipapar asap rokok dan tanpa diberi ekstrak etanol kulit apel manalagi. Kelompok perlakuan dibagi menjadi tiga kelompok yaitu P-1 (7 $\mathrm{mg} / \mathrm{KgBB}), \quad \mathrm{P}-2 \quad(14$ $\mathrm{mg} / \mathrm{KgBB}$ ), P-3 (28 mg/ KgBB) yang merupakan tikus bunting dipapar asap rokok kemudian diberikan ekstrak etanol kulit apel manalagi dengan dosis yang berbeda pada setiap kelompoknya. Pemberian paparan asap rokok dan ekstrak etanol kulit apel manalagi dilakukan mulai dari hari ke-6 hingga hari ke18 sejak tikus dinyatakan bunting. Pembedahan tikus untuk mengambil bayi tikus dilakukan pada hari ke-19. Bayi tikus yang telah lahir kemudian ditimbang berat badannya. Penilaian 
dilakukan dengan membandingkan berat badan bayi tikus dari tikus bunting pada kelompok kontrol dan kelompok perlakuan.

\section{Populasi dan Sampel}

Penelitian ini menggunakan sampel tikus betina jenis Rattus norvegicus galur wistar bunting sebagai hewan coba. Kriterian sampel yaitu tikus dengan berat badan 100-200 gram, bergerak aktif, usia 8-12 minggu, dan dalam kondisi nafsu makan yang baik. Dalam penelitian menggunakan 5 sampell untuk masing-masing kelompok, jadii jumlah keseluruhan ekor tikus adalah $5 \times 5=25$ ekor tikus.

\section{Variabel Penelitian}

Variabel bebas pada penelitian yaitu ekstrak etanol kulit apel manalagi dalam tiga dosis berbeda dan kandungan dalam paparan asap rokok. Variabel terikat dalam penelitian ini yaitu Berat Badan bayi tikus baru lahir dari tikus (Rattus Norvegicus Strain Wistar) bunting ketika lahir.

\section{Prosedur Penelitian}

Penelitian dimulai dengan melakukan adaptasi pada tikus selama minimal 7 hari. Selanjutnya, tikus betina dikawinkan dengan tikus jantan menggunakan perbandingan 1:1. Apabila keesokan harinya ditemukan vaginal pluaque, maka dinyatakan hari pertama kebuntingan pada tikus dan tikus dimasukkan kedalam kelompok perlakuan. Pada hari ke-6 hingga hari ke-18 kebuntingan, tikus dalam kelompok P1, P2 dan P3 diberikan esktrak etanol kulit apel manalagi sesuai dosis dan diberi paparan asap rokok serta $\mathrm{K}+$ hanya diberi paparan asap rokok. Pada hari ke19 kebuntingan, dilakukan pembedahan pada tikus bunting dan mengambil bayi tikus untuk ditimbang berat badannya menggunakan neraca digital analitik.

\section{Teknik Analisis Data}

Data dianalisa menggunakan ANOVA berfungsi membandingkan nilai rata-rata dari setiap kelompok. Selanjutnya, uji Post Hoc untuk tahu kelompok yang berbeda signifikan dari Anova, dan korelasi pearson bertujuan mengetahui besarnya perbedaan secara kualitatif kelompok yang berbeda secara signifikan dari hasil Uji Post Hoc.

\section{HASIL PENELITIAN}

Pada kelompok kontrol negatif (K-) rata-rata berat badan bayi tikus 4,51 gram dan pada kelompok kontrol positif $\left(\mathrm{K}_{+}\right)$, ratarata berat badan bayi mengalami penurunan hingga 2,81 gram yang merupakan kelompok dengan berat badan bayi terendah. Pada kelompok-P1 dengan pemberian paparan asapnya rokok serta ekstrak etanol kulit apel manalagi dosis $7 \mathrm{mg} / \mathrm{Kg}$ BB tikus/hari ratarata berat badan bayi tikus yaitu 4,49 gram yang merupakan ratarata berat badan bayi terendah diantara kelompok perlakuan, selanjutnya mengalami peningkatan pada kelompok-P2 diberikan paparan asapnya rokok serta ekstrak etanol kulit apel manalagi dosis $14 \mathrm{mg} / \mathrm{Kg}$ BB tikus/hari ratarata berat badan bayi tikus yaitu 4,70 gram, dan kembali mengalami peningkatan pada kelompok-P3 diberikan paparan asapnya rokok dan ekstrak etanol kulit apel manalagi dosis $28 \mathrm{mg} / \mathrm{Kg}$ BB tikus/hari dengan rata-rata berat badan bayi tikus adalah 5,06 gram. 


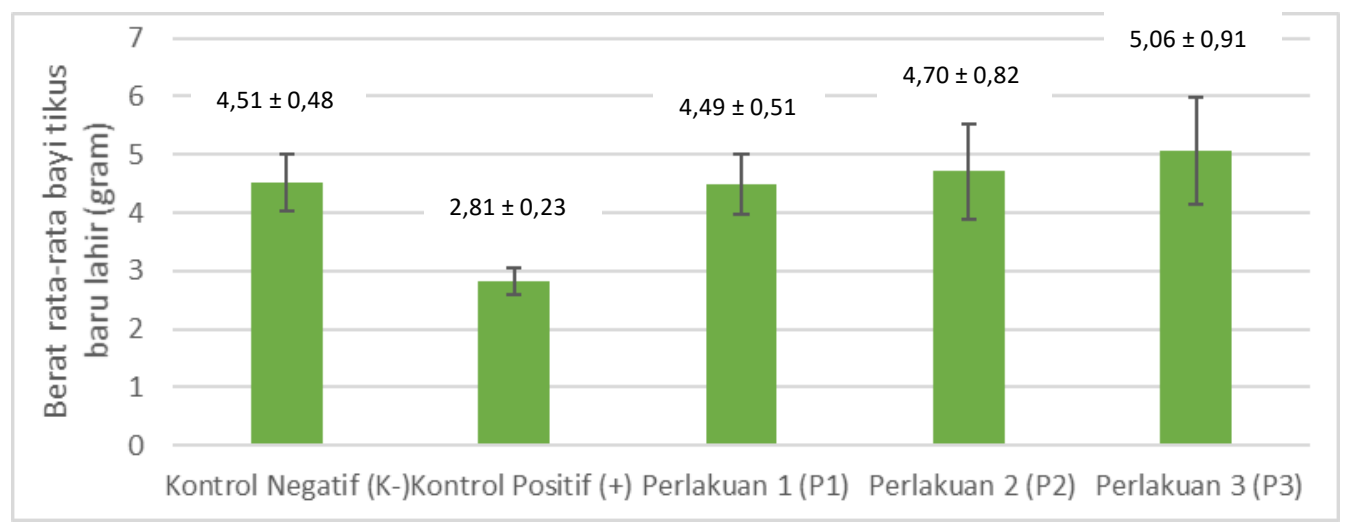

Grafik 1. Rata-Rata Berat Badan Bayi Tikus Baru Lahir

Pada grafik 1 terlihat bahwa pemberian ekstrak etanol kulit apel manalagi dapat meningkatkan berat badan bayi tikus baru lahir pada kehamilan yang cukup bulan (aterm), peningkatan berat badan bayi tikus baru lahir yang paling tinggi yaitu terdapat pada kelompok perlakuan 3 (P3) dengan pemberian dosis ekstrak etanol kulit apel manalagi sebesar $28 \mathrm{mg} / \mathrm{Kg}$ BB tikus/hari.

\section{ANALISA DATA}

Hasil uji normalitas, data dinyatakan normal dengan Shapiro -Wilk dengan $p=0,645$ ( $p>0,05)$ dan hasil test homogenitas $p=0,590$ ( $p>0$, 05) sehingga data yang digunakan homogen. Setelah data dinyatakan normal dan homogen, maka syarat untuk dilakukan uji One-Way ANOA terpenuhi.

Hasil yang didapatkan dari uji One-Way ANOVA adalah $\mathrm{p}=0,000$ $(\mathrm{p}<0,05)$, hasil tersebut menunjukkan terdapat perbedaan yang signifikan pada semua kelompok perlakuan setelah 13 hari dilakukan pemberian ekstrak etanol kulit apel manalagi dengan 3 dosis yang berbeda. Selanjutnya dilakukan yaitu uji Post Hoc Test dengan menggunakan uji Tukey $H S D$, untuk mengetahui perbedaan kelompok satu dengan kelompok lainnya yang berbeda secara signifikan dari hasil uji statitistik sebelumnya. Hasil uji Tukey HSD dinyatakan terdapat perbedaan secara signifikan antar dua kelompok apabila nilai $p<0,05$. Berikut tabel hasil uji Tukey HSD :

Tabel 1. Hasil Uji Tukey HSD

\begin{tabular}{|c|c|c|c|c|c|}
\hline $\begin{array}{l}\text { Kelo } \\
\text { mpok }\end{array}$ & $\mathrm{K}(-)$ & $\mathrm{K}(+)$ & $P-1$ & $\mathrm{P}-2$ & P-3 \\
\hline $\mathrm{K}(-)$ & & $0,004^{*}$ & 1,000 & 0,989 & 0,669 \\
\hline $\mathrm{K}(+)$ & & & $0,004^{*}$ & $0,001^{*}$ & $0,000^{*}$ \\
\hline P1 & & & & 0,986 & 0,646 \\
\hline $\mathrm{P} 2$ & & & & & 0,903 \\
\hline P3 & & & & & \\
\hline
\end{tabular}

Selanjutnya, hasil Sig. (2tailed) pada uji korelasi $\mathrm{p}=0,001$ menunjukkan terdapat perbedaan yang bermakna, antara kedua variabel. Pada hasil uji korelasi Pearson, $r=0,683$ (bernilai positif dan mendekat 1) menunjukkan bahwa korelasi antara kedua variabel yaitu kuat dan memiliki arah positif, berarti bahwa semakin tinggi dosis ekstrak etanol kulit apel manalagi yang diberikan semakin 
memiliki pengaruh untuk meningkatkan berat badan bayi tikus. Hasil uji regresi didapatkan nilai $R$ square yaitu 0,437 , menunjukkan bahwa $43,7 \%$ berat badan bayi tikus baru lahir dipengaruhi oleh ekstrak etanol kulit apel manalagi.

\section{PEMBAHASAN}

Perbedaan signifikan antara $\mathrm{K}$ - dengan $\mathrm{K}+$ dapat terjadi karena perbedaan perlakuan antar dua kelompok tersebut. Pada $\mathrm{K}+$ yang diberikan paparan asap rokok tanpa ekstrak etanol kulit apel memiliki rata-rata berat badan bayi tikus jauh lebih rendah dibandingkan dengan $\mathrm{K}$ - yang tidak diberikan paparan asap rokok maupun ekstrak etanol kulit apel. Penurunan berat badan bayi dapat terjadi karena asap rokok yang mengandung radikal bebas dalam jumlah yang tinggi. Radikal bebas(RB) mempunyaii reaktivitas tinggi, dengan cenderungan menarik elektron serta bisa merubah molekul menjadi radikal sebab bertambah atau hilangnya elektron di molekul lainnya. RB rusak molekul dengan cara menarik elektron nya hingga dapat rusak sel bahkan matinnya sel.

Pada setiap hisapan rokok akan dihasilkan \pm 1.041 molekul RB atau reactive oxygen species (ROS). Adanya radikal bebas dalam tubuh dapat diimbangi dengan mekanisme pertahanan dari dalam tubuh dengan produksi zat antioksdan, namun pada saat ROS meningkat melebihi sistem pertahanan tubuh, maka akan timbull stress oksidatif ${ }^{14}$. Stress oksidatif yang terjadi pada ibu hamil disebabkan karena ketidak seimbangan antioksidan dan oksidan dapat menyebabkan penurunan perfusi plasenta yang diakibatkan karena terjadinya disfungsi endotel vaskuler maternal ${ }^{15}$ Disfungsi endotel menyebabkan terjadinya vasokontriksi arteriola spiralis desidua, penurunan aliran darah ke plasenta, serta menurunnya suplai oksigen dan nutrisi ke janin sehingga proses pertumbuhan janin akan terganggu ${ }^{9}$.

Selain mengandung radikal bebas, dalam asap rokok juga mengandung senyawa kimia karbon monoksida (CO) dan nikotin. Nikotin yang terpapar oleh ibu hamil dapat menyebabkan perangsangan terhadap hormon katekolamin (adrenalin) yang memacu jantung serta tekanan darah dan pelepasan hormon katekolamin maternal juga dapat menyebabkan terjadinya vasokontriksi pada uterus. Hal ini dapat merubah denyut jantung janin dan aliran darah umbilikal, serta dapat mengiinduksi terjadinya hipoksia pada janin. Kandungan karbon monoksida yang juga terdapat dalam asap rokok dapat berpengaruh pada berkurangnya oksigen ke janin sehingga menyebabkan terjadinya hipoksia pada janin ${ }^{16}$.

Hasil uji statistik antara kelompok P1, P2 dan P3 memiliki perbedaan yang bermakna dengan $\mathrm{K}+$, namun tidak berbeda bermakna dengan K-. Hal ini menunjukkan bahwa kelompok tikus yang diberikan paparan asap rokok serta diberi ekstrak etanol kulit apel memiliki rata-rata berat badan bayi tikus yang sama dengan kelompok K- yang tidak diberi paparan asap rokok. Tidak terjadinya penurunan 
berat badan bayi tikus pada kelompok P1, P2, dan P3 dipengaruhi karna pemberian ekstrak etanol kulit apel manalagi yang mengandung senyawa phenol, flavonoid, dan asam phenolic yang lebih besar dibandingkan dengan daging buahnya. Beberapa senyawa phenol yang terdapat pada ekstrak kulit apel manalagi diantaranya yaitu (diukur dalam $\mathrm{mg} / \mathrm{g}$ ), asam clorogenic 0,568, epikatechin 1,36, ploridzin 0,207, Katekin 0,187, hiperoside 0,261, dan kuersetin $0,256 \mathrm{mg} / \mathrm{g}^{17}$. Salah satu senyawa yang juga terdapat pada kulit apel yaitu flavonoid, senyawa flavonoid yaitu golongan dari senyawa metabolit sekunder dihasilkan dari tumbuhan berfungsi sebagai antioksidan sehingga memiliki peran dalam mencegah kerusakan sel dan komponen selularnya oleh radikal bebas reaktif. Aktivitas antioksidan dari kelompok phenol dan flavonoid mereduksi RB bergantung pada jumlah gugus hidroksi pada struktur molekulnya ${ }^{18}$.

Aktifitas antioksidan yang diuji menggunakan metode DPPH pada ekstrak kulit apel lebih tinggi secara signifikan dengan aktifitas antioksidan pada daging buahnya ${ }^{17}$. Antioksidan akan lebih mudah breaksi dengan RB lebih dulu dibanding dengan molekul lainnya karena antioksidan memiliki sifat mudah oksidasi bersama molekul ${ }^{19}$.

Pada kelompok P1, P2, dan P3 yang diberikan paparan asap rokok, hal ini menyebabkan terjadinya peningkatan radikal bebas dalam tubuh tikus. Paparan asap rokok pada tikus bunting dapat menyebabkan terjadinya peningkatan jumlah radikal bebas dalam tubuh tikus yang dapat menimbulkan terjadinya stres oksidatif dan beresiko untuk melahirkan bayi tikus dalam kondisi berat badan yang rendah ${ }^{20}$. Stress oksidatif yang terjadi akan berdampak pada penurunan perfusi plasenta yang diakibatkan karena terjadinya disfungsi endotel vaskuler maternal ${ }^{15}$. Disfungsi endotel dapat menyebabkan resistensi pembuluh darah arteri uterina meningkat, membuat aliran darah ke plasenta menurun dan menyebabkan suplai oksigen menurun pada plasenta, sehingga dapat terjadi gangguan pertumbuhan janin hingga kematian janin $^{21}$. Namun, dengan pemberian ekstrak etanol kulit apel manalagi akan terjadi aktifitas antioksidan yang tinggi dan dapat menghambat reaksi berantai pada radikal bebas, karena antioksidan dapat bereaksi dengan radikal bebas untuk membentuk molekul yang stabil dan tidak berbahaya.

Salah satu kandungan senyawa pada ekstrak kulit apel yaitu flavonoid yang dapat memberi efek antioksidan dengan mencegah generasi ROS, dapat terjadi secara langsung menangkap ROS atau secara tidak langsung terjadi penigkatan enzim ${ }^{22}$. Flavonoid menangkap secara langsung superoksida serta peroxynitrite, terjadi karena super-oksida yang tertangkap, flavonoid meningkat kan bioavailabilitas NO dan menghambat proses pembentukan peroxynitrite. Flavonoid juga dapat mengambil peroxynitrite yang menyebabkan vacorelaxation endotellium dan mengganggu endotellium, akibatnya sirkulasi darah dalam arteri akan baik ${ }^{22}$. Hal ini dapat mencegah terjadinya vasokontriksi pada arteriola spiralis desidua yang berpengaruh pada perfusi plasenta, sehingga fungsi 
plasenta akan kembali normal dan pertumbuhan janin akan lebih optimal.

\section{SIMPULAN}

Pemberian ekstrak etanol kulit apel manalagi (Malus sylvetris Mill) dapat mencegah penurunan berat badan bayi tikus baru lahir pada tikus (Rattus norvegicus) bunting yang dipapar asap rokok.

Penggunaan dosis efektif ekstrak etanol kulit apel manalagi yang dapat mencegah penurunan berat badan bayi tikus baru lahir yaitu pada dosis pertama yaitu dosis $7 \mathrm{mg} / \mathrm{Kg} \mathrm{BB}$ tikus/hari.

\section{DAFTAR PUSTAKA}

1. Badan Pusat Statistik. 2013. Survey Demografi dan Kesehatan Indonesia (SDKI) 2012. Jakarta.

2. Kemenkes RI. 2014. Pusat Data dan Informasi Kementerian Kesehatan RI (InfoDATIN) Kondisi Pencapaian Program Kesehatan Anak Indonesia. Balitbang Kemenkes RI, Jakarta.

3. Dinkes Kota Malang. 2015. Profil Kesehatan Kota Malang 2014. Malang

4. Rasyid $P$ et al. Faktor Risiko Kejadian Bayi Berat Lahir Rendah di RSUD Prof. DR. H Aloei Saboe Kota Gorontalo Provinsi Gorontalo Tahun 2012, 2012, Hal. 11.

5. Eriksen, et al. The Tobacco Atlas 6th Edition. Georgia American Cancer Society, 2018.

6. Kemenkes RI. 2013. Riset Kesehatan
(Riskesdas). Balitbang Kemenkes RI, Jakarta

7. Jauniaux E., and Burton G. Morphological and Biological Effects of Maternal Exposure to Tobacco Smoke on The Feto-placental Unit. Early Human Development, 2007, 83(11): 699-706.

8. Fitria, et al. Merokok dan Oksidasi DNA. Sains Medika, 2013, 5(2): 113-120.

9. Cunningham et al., 2012. Obstetri William, 23rd ed., EGC, Jakarta

10. Jannata R., Gunadi A., dan Ermawati T. Daya Antibakteri Ekstrak Kulit Apel Manalagi ( Malus sylvestris Mill ) Terhadap Pertumbuhan Streptococcus mutans. Jurnal Universitas Jember, 2014, 2(1): 23-28.

11. Dinas Pertanian Jawa Timur. 2014. Produksi Apel Pertahun

12. Badan Pusat Statistik. 2010. Data Produksi Apel di Kota Malang Provinsi Jawa Timur. Jakarta.

13. Persada N. 2009. Pengaruh Ekstrak Kulit Apel Rome beauty dalam Mengurangi Kerusakan Histologis Hati Mencit. Tugas Akhir. Universitas Sebelas Maret Surakarta.

14. Mohamed $\mathrm{M}$ et al., Effect of Different Doses of Malaysian Honey on Reproductive Parameters in Adult Male Rats, Jurnal Andrologia, 2011, 44(s1):182-186.

15. Setiawan B., dan Insani D. Peroksidasi Lipid dan Stress Oksidatif pada Preeklampsia. Mutiara Medika, 2004, Vol. 4 (No. 2). 
16. Lee $J$ et al., Influence of Maternal Environmental Tobacco Smoke Exposure Assessed by Hair Nicotine Levels on Birth Weight, Asian Pacific Journal of Cancer Prevention, 2015, 16(7): 3029-3034.

17. Mihailovic $\mathrm{N}$ et al., Analysis of Phenolic in The Peel and Pulp of Wild Apples (Malus sylvetris (L.) Mill.), Journal of Food Composition and Analysis, 2017, 67: 1-9.

18. Banjarnahor, S., \& Artanti, N., Antioxidant Properties of Flavonoids, Medical Journal of Indonesia, 2014, 23(4): 239-244.

19. Khaira K. Menangkal Radikal Bebas dengan Antioksidan. Jurnal Sainstek, 2010, Vol. 2 No. 2: 183-187.

20. Esposito E et al., An Animal Model of Cigarette SmokeInduced in Utero Growth Retardation, Journal of Toxicology NIH Public Access, 2008, 246(2-3):193202.

21. Negi et al. Oxidative Stress and Preeclampsia, Advances in Life Science, 2011, 1 (1) : 20-3

22. Akhlaghi M., and Brian B. Mechanisms of Flavonoid Protection Against Myocardial Ischemia-reperfusion Injury, Journal of Molecular and Cellular Cardiology. 2009, 46 : 309-17. 